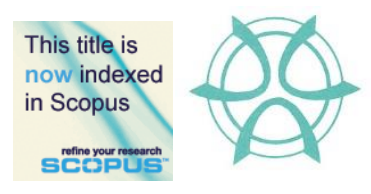

PLANNING MALAYSIA:

Journal of the Malaysian Institute of Planners

VOLUME 15 VOLUME 1 (2017), 357 - 368

\title{
A REVIEW ON SUSTAINABLE WELLBEING INDICATORS FOR HUMAN INTERRELATIONSHIPS WITH THE ENVIRONMENT
}

\author{
Aisyah Abu Bakar', Mariana Mohamed Osman², Syahriah Bachok³ ${ }^{3}$ Ismawi Zen ${ }^{4}$, \\ \& Muhammad Faris Abdullah ${ }^{5}$ \\ 1,2,3,4,5 Kulliyyah of Architecture and Environmental Design, \\ INTERNATIONAL ISLAMIC UNIVERSITY MALAYSIA
}

\begin{abstract}
The environment should appear not only as a commodity to humans but as an inspiring source that appeals to humans' ethical ability. In Malaysia, studies concerning factors influencing pro-environmental behaviours are vast. However, studies on interrelationships between humans and the contextual surroundings are scarce. Towards achieving sustainable well-being, it is undoubtedly important for humans to have conforming emotions, behaviours, cognitions and motivations towards the environment. This study intends to identify the determinants of human values and ethical behaviour concerning the environment towards developing a theoretical framework of interrelationship between human and environment.
\end{abstract}

Keyword: sustainable well-being, human interrelationships with the environment

Date Received: $30^{\text {th }}$ April 2016

Date of Acceptance: $30^{\text {th }}$ October 2016 
Aisyah Abu Bakar, Mariana Mohamed Osman, Syahriah, Ismawi Zen, Alias Abdullah, \& Muhammad Faris

An Assessment of Sustainable Wellbeing Indicators for Human Interrelationships with the Environment

\section{INTRODUCTION}

This study is a part of an ongoing research to discover variables of sustainable well-being for Malaysia at the local scale. Sustainable well-being in simplest understanding means to pursue well-being without compromising others' abilities to pursue their well-being (Kjell, 2011; Kajikawa, 2008; O'Brien, 2008). The term 'others' refer to all living and resourceful beings. This study recognizes 'others' as humans and environment. Variables of sustainable well-being manifests in human interrelationship with other humans and human interrelationship with the environment (Kjell, 2011). The term 'interrelationship' refer to mutual reliance between two groups, which in this case (i) between human and other humans, and (ii) between human and the environment. The variables are practical for national and international use in measuring the readiness and the extent of efforts of everyday practices towards sustainable wellbeing at the local scale. This paper focuses on theoretical exploration of the interrelationship between human and environment.

The natural resources have fulfilled many of humans' basic needs, such as water, food, materials and shelters. In return, human activities have been exploiting and polluting the environment (Kajikawa et al., 2007; Yarime, Takeda \& Kajikawa, 2010). The principal reason for this alarming issue is that humans have conceptualized the natural environment as the resources of utility and commodity (Kjell, 2011). Environment ought to inspire human's ethical ability. In pursuit of sustainable well-being, it is vital for humans to have conforming emotions, attitudes, cognitions and motivations that relate to their contextual environment (Kjell, 2011; Krajhanzl, 2010; Horayangkura, 2013). The ethical ability refers to positive human engagements with natural surroundings reflected in norms, lifestyles and outdoor skills (Krajhanzl, 2010). This paper demonstrates the theoretical framework of human interrelationship with environment towards developing the intended variables at the local scale. The variables serve as quantifiable indicators of mutual reliance between human and environment.

This paper discussed examples of findings from recent environmental studies from the year 2010 onwards to capture the variables involved in human interrelationship with the environment. This paper was presented at 2015 Asia Pacific International Conference on Environment-Behavior Studies. In association with the conference's follow up journals, the environmental studies were gathered from published articles of ajE-Bs and jABs. The purpose of limiting the sources is to establish parameters in determining the patterns of recent findings on human-related environmental studies, particularly in Malaysia. The selection of the papers depends on the relevance of the papers in examining the human-environment concerned issues as well as the addressed dynamics and factors involved in human interrelationship with the environment. 
PLANNING MALAYSIA:

Journal of the Malaysia Institute of Planners (2017)

\section{SUSTAINABILITY AND HUMAN WELLBEING}

Environmental sustainability acknowledges to the balance between the rate of depletion of natural resources and replenishment of natural resources (Schultz, 2002). Common scientific research fields that concern on environmental sustainability are forestry, fisheries and agriculture (Kajikawa et al., 2007; Yarime, Takeda \& Kajikawa, 2010). A number of authors found that there is a lack of study on the relations of well-being with mentioned research fields (Yarime, Takeda \& Kajikawa, 2010; Kjell, 2011). Sustainability research objectives include the pursuit of happiness of both present and the future generation (Kajikawa, 2008). There is a large number of authors that recognize well-being within sustainability (Kjell, 2011; O’Brien, 2008). However, the nature of the "well-being" has not been clearly explained (Horayangkura, 2013). Therefore, profound understanding of well-being from the view of sustainability research is in need.

The significance of sustainable well-being lies in the interdependencies between a variety of interaction processes and systems (Lele \& Noorgard, 1996). As asserted by O'Hara (1998), every so often human interaction systems are in tension and not mutually compatible. Interdependencies can be a result of wellbeing that is sustained at another's expense. The studies of social context illustrated how one person's well-being may source from ill-being of others, which in reverse is also true (Lele \& Noorgard, 1996; O'Hara, 1998; Lazarus, 2003; Kjell, 2011). Thus, interdependencies between human and the contexts which he acts in are a significant measure of sustainable well-being (Lazarus, 2003; Horayangkura, 2013). The theories of sustainable well-being suggested that sustainable well-being is achievable through supportive and congruent interaction system (Kjell, 2011; Krajhanzl, 2010; Lazarus, 2003). In other words, for well-being to be sustained, the entities in the interaction system must also achieve compatible and cohesive wellness. The entities, for the most part, are people and environment.

Sustainable well-being between human and environment is achievable when humans and environment are supportive of each other and relied on one another for mutual wellness. As achieving human well-being growingly followed by environment ill-being, the interrelationship between human and environment rise in pressure. Among recognized causes of this pressure are sheer neglectfulness, lack of knowledge and experiences and hesitant to change attitudes and lifestyles (Krajhanzl, 2010). However, there are more to the barriers of environmental ethics. Other factors which lack in academic discussions are individual personality, intentional and unintentional interaction with natural environment, and external conditions such as economic constraints and cultural roots (Krajhanzl, 2010; Lim, 2011; Delima \& Zaman, 2012).

Therefore, more theoretical understanding and observable indicators are necessary to comprehensively discern the interrelationship between human and 
Aisyah Abu Bakar, Mariana Mohamed Osman, Syahriah, Ismawi Zen, Alias Abdullah, \& Muhammad Faris An Assessment of Sustainable Wellbeing Indicators for Human Interrelationships with the Environment

environment. The following subsections discuss on common findings of humanrelated environmental studies as well as dimensions and factors influencing human interrelationship with the environment. The outcome is used to develop quantifiable subjective indicators of human interrelationship with the environment suitable for Malaysia.

\section{RELATED ENVIRONMENTAL STUDIES IN MALAYSIA}

Human-related environmental studies refer to broad interdisciplinary academic fields that investigate the interaction between human and environment in the attempt to provide a solution to complex issues. The study fields cover topics relating to the natural environment, built environment, behavioural studies relating to the environment and the relationships between them (Knight, 2015; Delgado, Aceituno \& Loaiza, 2015). Horayangkura (2013) stresses the need for profound theories and observable measures on human interrelationship with the environment for architectural designs. The field of environmental psychology can assist to elucidate understanding of interrelationships between human and environment for more people-centric built environment. According to Krajhanzl (2010), the dynamics of human interaction with the environment is a very wide web. The model cannot be static, but it changes from time to time as determinants of the interrelations between human and environment evolve. Table 1, Table 2, Table 3 and Table 4 summarized findings from human-related environmental papers in ajE-Bs and $\mathrm{j} A B s$.

Table 1 Environmental Behaviour

\begin{tabular}{|c|c|}
\hline Summary of Findings & Authors \\
\hline $\begin{array}{l}\text { Inception of ecopsychology elements in environmental education } \\
\text { increases attitudes towards environment. }\end{array}$ & $\begin{array}{l}\text { Kamidin et al., } \\
2010\end{array}$ \\
\hline $\begin{array}{l}\text { Gender and parents' education levels have no effect on conservation } \\
\text { behaviour. Urban and rural strata and faculties have a linear effect } \\
\text { on conservation behaviour. }\end{array}$ & $\begin{array}{l}\text { Asmuni et al., } \\
2010\end{array}$ \\
\hline $\begin{array}{l}\text { Students preferred the convenient modes of transportation: personal } \\
\text { cars over the public transports due to needs and constraints. }\end{array}$ & $\begin{array}{l}\text { Singhirunnusorn } \\
\text { et al.2011 }\end{array}$ \\
\hline $\begin{array}{l}\text { Recycling attitudes cannot guarantee recycling behaviour. } \\
\text { Consumers with high collectivistic values have high recycling } \\
\text { behaviours than consumers with high materialistic and } \\
\text { individualistic values. }\end{array}$ & $\begin{array}{l}\text { Abdul Latif and } \\
\text { Omar, } 2012\end{array}$ \\
\hline $\begin{array}{l}\text { Knowledge, attitude and recycling behaviour have significant and } \\
\text { positive correlations. }\end{array}$ & $\begin{array}{l}\text { Singhirunnusor et } \\
\text { al., } 2012\end{array}$ \\
\hline $\begin{array}{l}\text { Sense of community and place develops willingness to take } \\
\text { responsibility for more than their immediate surroundings. }\end{array}$ & Laurens, 2012 \\
\hline $\begin{array}{l}\text { Situational factor has significant and direct effect on both recycling } \\
\text { behaviour and intention to recycle. Intention to recycle is a partial } \\
\text { mediator in linking situational factors to recycling behaviour. }\end{array}$ & $\begin{array}{l}\text { Abdul Latif et al., } \\
2012\end{array}$ \\
\hline
\end{tabular}


PLANNING MALAYSIA:

Journal of the Malaysia Institute of Planners (2017)

Communication barely occur between designers and building users.

Due to continual cultural factors and adaptations, inclusion of Horayangkura, environment-behaviour in architectural practices seemed 2013

impossible.

Table 2 Outdoor Environment

\begin{tabular}{|c|c|}
\hline Summary of Findings & Authors \\
\hline $\begin{array}{l}\text { The community believed that it was necessary to maintain stability } \\
\text { of social life to provide peace and stability to the forest. }\end{array}$ & $\begin{array}{l}\text { Zahari et al., } \\
2010\end{array}$ \\
\hline $\begin{array}{l}\text { Users feel safe in surrounding with vegetation that was well } \\
\text { maintained, not dense, provided a clear view, clean and spacious. } \\
\text { Gender and age had no significant relationship on personal safety in } \\
\text { public park. }\end{array}$ & $\begin{array}{l}\text { Maruth } \\
2010\end{array}$ \\
\hline $\begin{array}{l}\text { Influential factors affecting house value were (i) variety of park } \\
\text { elements, (ii) conceptual or design of the park, (iii) distance to the } \\
\text { park, (iv) views towards the park, and (v) active areas in the park } \\
\text { facing the house, respectively. }\end{array}$ & $\begin{array}{l}\text { Othman \& } \\
\text { Nawawi, } 2010\end{array}$ \\
\hline $\begin{array}{l}\text { The lower the satisfaction levels of the patients due to bed } \\
\text { positioning in relation to window and inaccessibility to outdoor } \\
\text { garden, the longer their recovery process. }\end{array}$ & $\begin{array}{l}\text { Ghazali \& Yusoff } \\
\text { Abbas, } 2011\end{array}$ \\
\hline $\begin{array}{l}\text { There exist positive and strong correlation between diversity of green } \\
\text { infrastructure and (i) physical well-being, (ii) cognitive well-being, } \\
\text { and (iii) social well-being. }\end{array}$ & $\begin{array}{l}\text { Mansor } \\
2012\end{array}$ \\
\hline $\begin{array}{l}\text { The pre-test indicated there was a relationship between people's } \\
\text { accessibility to green open space and their corresponding social } \\
\text { health and behaviour. Most of respondents showed very few cases } \\
\text { on physical symptoms, stress, and anxiety disorder. }\end{array}$ & $\begin{array}{l}\text { Singhirunnusorn } \\
\& \text { Sahachai- } \\
\text { saeree, } 2012\end{array}$ \\
\hline $\begin{array}{l}\text { Stimulation of natural elements is statistically effective on (IV) and } \\
\text { (i) flexibility of functions, (ii) play-participation, and (iii) curiosity } \\
\text { (DV). }\end{array}$ & Fai \\
\hline $\begin{array}{l}\text { Urban-rural strata, age and gender had significant effect on outdoor } \\
\text { walking speed. Walking distance and walking time were dependent } \\
\text { on physical ability, stamina health, and availability of pedestrian } \\
\text { space, visual appropriateness, and obstacles. }\end{array}$ & Azn \\
\hline $\begin{array}{l}\text { Park users were equally distributed among gender and age groups } \\
\text { which implied safety and implausibility of unwarranted juvenile. } \\
\text { Human behaviours response to the physical setting of the park }\end{array}$ & $\begin{array}{l}\text { Ngesar } \\
2013\end{array}$ \\
\hline
\end{tabular}


Aisyah Abu Bakar, Mariana Mohamed Osman, Syahriah, Ismawi Zen, Alias Abdullah, \& Muhammad Faris An Assessment of Sustainable Wellbeing Indicators for Human Interrelationships with the Environment

Table 3 Environmental Policy

\begin{tabular}{l}
\hline Summary of Findings \\
Failing to enforce regulations due to limited resources had increase \\
pressure on SWM industry and intensify barriers to residents' \\
participation in recycling and waste separation. Awareness and Lim, 2010 \\
behavioural change were crucial to improve the situation. \\
EEC of Malaysian managers was statistically explained by (i) \\
regulation aspects, (ii) financial aspects and (iii) stakeholder \\
information Costs of environmental efforts help to lower cost of Delima \& \\
operations, reduce environmental impact and improve corporate Zaman, 2012 \\
image. Stakeholder involvement impart pressure and promote \\
awareness.
\end{tabular}

\begin{tabular}{ll}
\hline \multicolumn{3}{c}{ Table 4 Environmental Stress and Pollution } & \\
\hline Summary of Findings & Authors \\
\hline $\begin{array}{l}\text { Environmental stressed are statistically related to housing size, Sahari et } \\
\text { surrounding living area and exposure to natural disaster. Housing size }\end{array}$ & $\begin{array}{l}\text { al., } 2012 \\
\text { Improper construction process and procedures during alterations of houses }\end{array}$ \\
$\begin{array}{l}\text { often resulted to issues to the house and surrounding areas. This include } \\
\text { natural environment, health and quality of life. }\end{array}$ & 2012 \\
$\begin{array}{l}\text { There exists simultaneous relationship between per capita income and per } \\
\text { capita pollutant emission. }\end{array}$ & $\begin{array}{l}\text { Borhan et } \\
\text { al., } 2013\end{array}$ \\
$\begin{array}{l}\text { People living in tropical climate such as Malaysia adapted to higher } \\
\text { temperature, more humid and less breezy conditions. }\end{array}$ & 2013 \\
\hline
\end{tabular}

The tables summarize the findings and highlight important variables involved from the selected articles of human-environmental studies. The pattern of the summary suggested that a majority of the studies tend to examine sociopsychological aspects of human-environment relations. The findings provide understanding on how human-environmental studies are conducted and the dynamics or relationships between the variables tested in the research. Highlighted key variables from each article can be used to formulate the indicators of human interrelationship with the environment.

\section{DIMENSIONS OF HUMAN-ENVIRONMENT INTERRELATIONSHIPS}

Dimensions of human interrelationship with environment refer to the locations where variables of human interrelationship with environment manifested. That is the settings or conditions to which interaction between human and environment occur. Human interaction with the environment can be influenced by internal factors and external factors (Krajhanzl, 2010). Internal factors refer to the physical and the mental aspects of the individuals while the external factors refer to the environmental surrounding of the individuals. Internal factors vary from personality and lifestyle, commitment and ability while interacting with nature and responsible behaviour towards the environment. External factors vary from 
legalities, cultural and social values, public amenities and economical aspects. There are four dimensions of human interrelationship with the environment. The first dimension is Individual Personality which manifests in lifestyle, life values and personal qualities (Schwartz, 1992; Nickerson, 2003; Krajhanzl, 2010; Kamidin et al., 2011; Krajhanzl, 2010). The second dimension is Interaction with Nature which manifests in the need to interact, norms, commitment, abilities and skills relating to natural environment (Kaplan \& Talbot, 1983; Gifford, 1997; Kaiser, 1999; Bell et al., 2005; Bechtel \& Churchman, 2002; Krajhanzl, 2010). The third dimension is Environmental Behaviour which manifests in sensitivity, concerns and behaviour towards environment (Schmuck \& Schultz, 2002; Bechtel \& Churchman, 2002; Clayton \& Myers, 2003; Krajhanzl, 2010). The fourth and final dimension is External Control which manifests in economic development, legalities, physical context, cultural roots and social values (Bechtel \& Churchman, 2002; Saunders, 2003; Krajhanzl, 2010).

\section{Potential Indicators of Human-Environment Interrelationships}

Based on the literature reviews and findings from articles in ajE-Bs and jABs (Refer to Table 1, Table 2, Table 3 and Table 4), the potential subjective indicators are developed (Refer to Table 5) and categorized under the four dimensions of human interrelationship with environment.

Table 6 Potential Indicators for Human Interrelationships with the Environment

\begin{tabular}{|c|c|c|c|}
\hline $\begin{array}{l}\text { Dimen } \\
\text {-sions }\end{array}$ & $\begin{array}{l}\text { Manifesta } \\
\text {-tion }\end{array}$ & Potential Indicators & Sources \\
\hline $\begin{array}{l}\text { Indivi- } \\
\text { dual } \\
\text { Perso- } \\
\text { nality }\end{array}$ & $\begin{array}{l}\text { Lifestyles, } \\
\text { life values } \\
\text { and } \\
\text { personal } \\
\text { qualities }\end{array}$ & $\begin{array}{l}\text { Levels of consumerism, } \\
\text { materialism, collectivism and } \\
\text { individualism, extent of voluntary } \\
\text { modesty, conformity and } \\
\text { indolence, sense of control. }\end{array}$ & $\begin{array}{l}\text { Kamidin et al., 2011; } \\
\text { Kamarul Zahari et al. et } \\
\text { al., 2010; }\end{array}$ \\
\hline $\begin{array}{l}\text { Interac } \\
\text {-tion } \\
\text { with } \\
\text { Nature }\end{array}$ & $\begin{array}{l}\text { The need } \\
\text { to interact } \\
\text { with } \\
\text { nature, } \\
\text { norms, } \\
\text { commit- } \\
\text { ment, } \\
\text { abilities } \\
\text { and skills } \\
\text { relating to } \\
\text { natural } \\
\text { environ- } \\
\text { ment }\end{array}$ & $\begin{array}{l}\text { Personal health in association with } \\
\text { surrounding, time spent in open air, } \\
\text { presence of natural objects at home, } \\
\text { extent of exposure to nature during } \\
\text { work hours, able to cope outdoors } \\
\text { physically, emotionally and } \\
\text { intellectually (relating to skill and } \\
\text { knowledge), used to various types } \\
\text { of weather and common outdoor } \\
\text { temperature, able to see and hear } \\
\text { what others miss, notice scientific } \\
\text { details, in harmony with nature, } \\
\text { able to recall experiences with } \\
\text { nature. }\end{array}$ & $\begin{array}{l}\text { Kamidin et al., 2011; } \\
\text { Kamarul Zahari et al. et } \\
\text { al., 2010; } \\
\text { Maruthaveeran, 2010; } \\
\text { Shukur et al., 2010; } \\
\text { Mansor et al., 2012; } \\
\text { Singhirunnusorn and } \\
\text { Sahachaisaeree, 2012; } \\
\text { Faizi, et al., 2013; } \\
\text { Azmi, et al., 2013; } \\
\text { Ghazali \& Mohamed } \\
\text { Yusoff Abbas, 2011; } \\
\text { Ngesan et al., 2013; } \\
\text { Nasir et al., 2013 }\end{array}$ \\
\hline
\end{tabular}


Aisyah Abu Bakar, Mariana Mohamed Osman, Syahriah, Ismawi Zen, Alias Abdullah, \& Muhammad Faris An Assessment of Sustainable Wellbeing Indicators for Human Interrelationships with the Environment

\begin{tabular}{|c|c|c|c|}
\hline $\begin{array}{l}\text { Envi- } \\
\text { ron- } \\
\text { mental } \\
\text { Beha- } \\
\text { viour }\end{array}$ & $\begin{array}{l}\text { Environ- } \\
\text { mental } \\
\text { sensiti- } \\
\text { vity } \\
\text { concerns, } \\
\text { and } \\
\text { behaviour }\end{array}$ & $\begin{array}{l}\text { Motivated to understand and } \\
\text { preserve nature and environment, } \\
\text { acquire whole range of pro- } \\
\text { environmental habits, concern on } \\
\text { environmental damage, willing to } \\
\text { reduce needs for the preservation of } \\
\text { environment, involved in public } \\
\text { activities or political programs. }\end{array}$ & $\begin{array}{l}\text { Asmuni et al., 2011; } \\
\text { Singhirunnusorn et al., } \\
\text { 2011; Abdul Latif et al., } \\
\text { 2012; Singhirunnusor et } \\
\text { al., 2012; Laurens, } \\
\text { 2012; Singhirunnusorn } \\
\text { et al., 2012; } \\
\text { Horayangkura, } 2013\end{array}$ \\
\hline $\begin{array}{l}\text { Exter- } \\
\text { nal } \\
\text { Condi- } \\
\text { tion }\end{array}$ & $\begin{array}{l}\text { Economic } \\
\text { developm } \\
\text { ent, } \\
\text { legalities, } \\
\text { physical } \\
\text { context, } \\
\text { cultural } \\
\text { roots and } \\
\text { social } \\
\text { values }\end{array}$ & $\begin{array}{l}\text { Affordability, availability, } \\
\text { common collective needs, } \\
\text { environmental pollution and stress, } \\
\text { waste handling, animal abuse, } \\
\text { traditions, moral rules, religious } \\
\text { and value system, influence of } \\
\text { organizations and employers, } \\
\text { availability of conducive } \\
\text { environment, } \\
\text { environmental condition, traffic } \\
\text { infrastructure, civic amenities, } \\
\text { waste management regulations, and } \\
\text { enforced laws. }\end{array}$ & $\begin{array}{l}\text { Kamarul Zahari et al. et } \\
\text { al., 2010; Lim, 2011; } \\
\text { Delima \& Zaman, 2012; } \\
\text { Sahari et al., 2012; } \\
\text { Isnin, et al., 2012; } \\
\text { Borhan et al., 2013; } \\
\text { Nasir et al., } 2013\end{array}$ \\
\hline
\end{tabular}

Table 5 shows the potential indicators of human interrelationship with the environment which are yet to be statistically confirmed. The potential indicators are gathered from the literature reviews and summarized findings of selected articles. The potential indicators are organized under dimensions of the interdependencies between human and the environment. The dimensions are the location where the indicators are found. The manifestation indicates the expression or demonstration of the dimensions. Finally, the indicators proxy the manifestations and dimensions of the interdependencies. In other words, the indicators provide ways for the interdependencies between human and environment to be gauged.

\section{CONCLUSION}

This exploratory review focuses on developing potential quantifiable subjective indicators of human interrelationship with the environment at the local scale. The literature review is important to establish understanding of operational terms and variables in the theory of human interrelationship with the environment. The review also distinguishes the determinants and the dimensions of the interdependencies. Previous studies which attempted to determine relationship between human and environment have assisted this research to recognize important factors and potential indicators for the interdependencies. The indicators are valuable to measure the readiness of the locals in embracing sustainable well-being in their lifestyle. The indicators are also useful to indicate 
the extent of current lifestyles that incorporates relations between human and environment. Other opportunities of use include additional indicators for the environmental component in the current national well-being reports. The indicators serve as helpful data for policy review, which before was difficult to evaluate due to lack of unquantifiable data (MWR, 2013).

This study is a part of an ongoing research to develop sustainable wellbeing model for Malaysia. The limitation of this paper is the lack of empirical data to statistically prove the presence of dimensions of human interrelationship with the environment. The study will also need to assess more relevant and reliable publish academic sources especially from social indicator research towards finalizing the subjective indicators of human interrelationship with the environment. Apart from establishing potential indicators, reviewing ajE-Bs and jABs articles enable the researcher to distinguish the pattern of human-related environmental research particularly in Malaysia. The next challenge of the study is to substitute the potential indicators into questionnaire inquiries in comprehensive yet concise manner, which are understandable to the targeted respondents. During the analysis stage, the dimensions of the interdependencies between human and the environment will be the latent variables and the finalized indicators will be the observed variables. The data obtained and analysed from the questionnaires will determine if the dimensions of human interrelationship with the environment do in fact multivariately correlated and contribute to sustainable well-being.

\section{ACKNOWLEDGEMENTS}

This research was supported by MyGRANTS. This paper was presented at 2015 Asia Pacific International Conference on Environment-Behaviour Studies.

\section{REFERENCES}

Abdul Latif, S., \& Omar, M. S. (2012). Determinants of recycling behavior in Tioman Island. Journal of Asian Behavioral Studies, 2, 39-50.

Asmuni, S., Mohd. Khalili, J., \& Mohd. Zain, Z. (2012). Sustainable consumption practices of university students in Selangor, Malaysia. Journal of Asian Behavioral Studies, 2, 73-82.

Azmi, D. I., Abdul Karim, H., \& Mohd Amin, M. Z. (2013). Walking behavior of urban and rural streets. Journal of Asian Behavioral Studies, 11, 97-110.

Bechtel, R. B., \& Churchman, A. (2002). The new handbook of environmental psychology. New York: John Wiley.

Bell, P. A. (2001). Environmental psychology. 5th edition. Fort Worth, TX: Harcourt College Publishers.

Borhan, H., Ahmed E. M., \& Hitam, M. (2013). CO2, quality of life and economic growth in East Asian 8. Journal of Asian Behavioral Studies, 3(8), 13-24.

Clayton, S., \& Myers, G. (2009). Conservation psychology: Understanding and promoting human care for nature. Chichester, UK: Wiley-Blackwell. 
Aisyah Abu Bakar, Mariana Mohamed Osman, Syahriah, Ismawi Zen, Alias Abdullah, \& Muhammad Faris An Assessment of Sustainable Wellbeing Indicators for Human Interrelationships with the Environment

Delgado, M., Aceituno, F. J., \& Loaiza N. (2015). Multidisciplinary studies on the human-environment interaction during the initial peopling of the Americas. Quarterly International, 363, 1-3.

Delima, M., \& Zaman, K. (2012). Environmental ethical commitment (EEC): factors that affect Malaysian business corporations. Journal of Asian Behavioral Studies, 2 $11-22$.

Faizi, M., Azaria A. K., \& Maleki, S. N. (2013). Design guidelines of residential environments to stimulate children's creativity. Journal of Asian Behavioural Studies, 3, 25-36.

Ghazali R., \& Abbas, M. Y. (2011). Paediatric wards: healing environment assessment. Asian Journal of Environment-Behavior Studies, 2, 63-75. doi: 10.1016/j.sbspro.2012.12.217

Gifford, R. (1997). Environmental psychology: Principles and practice (2nd Edition) Boston: Allyn \& Bacon.

Horayangkura, V. (2012). Incorporating environment-behavior knowledge into the design process: an elusive challenge for architects in the 21st century. Procedia - Social and Behavioral Sciences, 50, 30-41. doi: 10.1016/j.sbspro.2012.08.013

Isnin, Z., Ramli, R., Hashim A. E., \& Ali, I. M. (2012). Are house alterations sustainable? Journal of ASIAN Behavioral Studies, 2, 1-14.

Kaiser, F. G. (1999). Ecological behavior, environmental attitude, and feelings of responsibility for the environment. European Psychologist, 2(4), 59-74.

Kajikawa, Y. (2008). Research core and framework of sustainability science. Sustainability Science, 3(2), 215-239.

Kajikawa, Y., Ohno, J., Takeda, Y., Matsushima, K., \& Komiyama, H. (2007). Creating an academic landscape of sustainability science: an analysis of the citation network. Sustainability Science, 2(2), 221-231.

Kamarul Zahari, N. F., Omar M., \& Daim, S. (2011). Lawad, Ye' Yo' and Tum Yap: The manifestation of forest in the lives of the Bateks in Taman Negara National Park. Journal of Asian Behavioral Studies, 1, 29-40. doi: 10.1016/j.sbspro.2012.04.181

Kamidin, T., Muda, A., Roslan, S., Konting, M. M., Md Jahi, M., \& Rashid, N. A. (2011). Ecopsychology elements in environmental education as to strengthen attitudes towards the environment. Journal of ASIAN Behavioral Studies, 1, 17-28.

Kaplan, S., \& Talbot, J. (1983). Psychological benefits of a wilderness experience. In I. Altman et al. (Eds.), Behavior and the natural environment. New York: Plenum Press.

Kjell, O. N. (2011). Sustainable well-being: A potential synergy between sustainability and well-being research. Review of General Psychology, 15(3), 255-266.

Knight, C. G. (2015). Human-environment interactions: case studies. International Encyclopaedia of the Social \& Behavioral Sciences (2nd Edition). Pp. 405-409.

Krajhanzl, J. (2010). Environmental and pro-environmental behavior. Social and Health, 21, 251-274.

Laurens, J. M. (2012). Intervention program to change the pro-environmental behavior of the riverside community. Journal of ASIAN Behavioral Studies, 2, 45-56.

Lazarus, R. S. (2003). Does the positive psychology movement have legs? Psychological Inquiry, 14(2), 93-109. 
Lele, S., \& Norgaard, R. B. (1996). Sustainability and the scientist's burden. Conservation Biology, 10(2), 354-365.

Lim, M. (2011). Measuring waste in Malaysia: A neglected approach. Journal of Asian Behavioral Studies, 1, 41-54. doi: 10.1016/j.sbspro.2012.04.182

Malaysia Wellbeing Report (2013). The Malaysian Wellbeing Index 2013. Putrajaya: Economic Planning Unit, Prime Minister's Department.

Mansor, M., Said, S., \& Mohamad, S. (2012). Experiential Contacts with Green Infrastructure's Diversity and Well-being of Urban Community. Asian Journal of Environment-Behaviour Studies, 49, 33-48. doi: 10.1016/j.sbspro.2012.07.024

Maruthaveeran, S. (2012). The perception of social safety in a green environment: a preliminary study at the Kepong Metropolitan Park. Journal of Asian Behavioral Studies, 1, 45-56.

Nasir, R. A., Ahmad S. S., \& Zain-Ahmed, A. (2013). Adaptive outdoor thermal comfort at an urban park in Malaysia. Journal of Asian Behavioral Studies, 3, 1-16.

Ngesan, M. R., Abdul Karim, H., \& Zubir, S. S. (2013). Relationship between night-time leisure behaviour and urban park setting in Shah Alam. Asian Journal of Environment-Behavior Studies, 4. doi: 10.1016/j.sbspro.2012.12.239

Nickerson, R S. (2003). Psychology and environmental change. New Jersey, London: Lawrence Erlbaum Associates, Publishers.

O'Brien, C. (2008). Sustainable happiness: how happiness studies can contribute to a more sustainable future. Canadian Psychology-Psychologie Canadienne, 49(4), 289-295.

O'Hara, S. (2001). The economics of nature and the nature of economics. In C. Cleveland, D. Stern \& R. Costanza, (Eds.), The challenges of valuation: Econolical economics between matter and meaning (pp. 89-107). Cheltenham, U.K.: Edward Elgar.

O'Hara, S. U. (1998). Internalizing economics: Sustainability between matter and meaning. International Journal of Social Economics, 25(2-4), 175-195.

Sahari, S. H.., Yusup Mohd Yaman, Awang, S., and Awang, R. (2012). Part-time adult students in Sarawak and environmental stress factors. Journal of Asian Behavioral Studies, 2, 47-57.

Saunders, C. D. (2003). The emerging field of conservation psychology. Human Ecology Review, 2(10), 137-149.

Schmuck, P., \& Schultz, W. (2002). Psychology of sustainable development. Boston: Kluwer Academic Publishers.

Schwartz, S. H. (1992). Universals in the content and structure of values: Theoretical advances and empirical tests in 20 countries. Advances in Experimental Social Psychology. San Diego: Academic Press.

Shukur, F., Othman N., \& Nawawi, A. H. (2010). The values of parks to the house residents. Asian Journal of Environment-Behavior Studies, 1, 85-94. doi: 10.1016/j.sbspro.2012.07.033

Singhirunnusorn, K., \& Sahachaisaeree, N. (2012). Effects of green open space on social health and behavior of urban residents: a case study of communities in Bangkok. Procedia - Social and Behavioral Sciences, 36, 449-455. doi: 10.1016/j.sbspro.2012.03.049 
Aisyah Abu Bakar, Mariana Mohamed Osman, Syahriah, Ismawi Zen, Alias Abdullah, \& Muhammad Faris An Assessment of Sustainable Wellbeing Indicators for Human Interrelationships with the Environment

Singhirunnusorn, W., Donlakorn, K., \& Kaewhanin, W. (2012). Household recycling behaviors and attitudes toward Waste Bank Project: Mahasarakham Municipality. Asian Journal of Environment-Behaviour Studies, 36, 35-48. doi: 10.1016/j.sbspro.2012.03.075

Singhirunnusorn, W., Luesopa, P., Pansee, J., \& Sahachaisaeree, N. (2011). Students' behavior towards energy conservation and modes of transportation: a case study in Mahasarakham University. Asian Journal of Environment-Behavior Studies, 2, 62-70. doi: 10.1016/j.sbspro.2012.02.147

Yarime, M., Takeda, Y., \& Kajikawa, Y. (2010). Towards institutional analysis of sustainability science: a quantitative examination of the patterns of research collaboration. Sustainability Science, 5(1), 115-125. 